\title{
Risk Factors for Subtypes of Children with Speech Sound Disorders Classified by Linguistic Symptoms
}

\author{
Minkyeong $\mathrm{Pi}^{\mathrm{a}}$, Seunghee $\mathrm{Ha}^{\mathrm{b}}$ \\ ${ }^{a}$ Graduate Program in Speech Language Pathology, Hallym University, Chuncheon, Korea \\ ${ }^{b}$ Division of Speech Pathology and Audiology, Audiology and Speech Pathology Research Institute, Hallym University, Chuncheon, Korea
}

Correspondence: Seunghee $\mathrm{Ha}, \mathrm{PhD}$ Division of Speech Pathology and Audiology, Audiology and Speech Pathology Research Institute, Hallym University, 1 Hallymdaehak-gil, Chuncheon 24252, Korea

Tel: $+82-33-248-2215$

Fax: +82-33-256-3420

E-mail: shha@hallym.ac.kr

Received: October 5, 2021

Revised: November 1, 2021

Accepted: November 1, 2021
Objectives: The purpose of this study is to investigate 22 risk factors for speech sound disorders (SSDs) and to find out whether there are differences in risk factors for each subtype of SSDs of Dodd's model. Methods: Sixty-two children with SSDs aged 3-9 years participated in the study, and 22 risk factors reported in literature were investigated through parental interviews and a nonverbal intelligibility test. Children with SSDs were divided into children with articulation disorders, phonological delays, and consistent/inconsistent phonological disorders. Results: As a result of the principal component analysis, 22 risk factors were classified into 1) language and gross motor development, 2) gender and early development, 3) otitis media with effusion, 4) socioeconomic status, and 5) family history. Among all risk factors, only general developmental delay around 2 years of age showed a significantly different frequency among subtypes of SSDs. Conclusion: This study directly investigated the risk factors of children with SSDs and classified a number of risk factors into five categories. This study suggests that if children show early general developmental delays, they should be closely monitored and early evaluation and interventions should be planned.

Keywords: Risk factors, Speech sound disorders, Principal component analysis
말소리장애 아동은 다양한 특성을 보이는 이질적인 집단이기 때 문에 진단과 치료를 위해서 원인 또는 말소리 처리과정, 혹은 아동 의 언어학적 증상에 따라 분류해야 한다는 의견들이 지속적으로 제기되었다(Dodd, 2014; Lewis et al., 2006; Pascoe, Stackhouse, \& Wells, 2005; Shriberg et al., 2010; Stackhouse \& Wells, 1997). 이 논 쟁의 주요 쟁점 중 하나는 말소리장애 아동의 말 발달에 대한 위험 요인의 영향이다. 말소리장애 아동은 말 능력, 언어 능력 이외에도 여러 위험요인이 상호작용하여 증상을 나타낸다. 말소리장애 아동 에게 내재된 위험요인이 모두 말소리장애의 원인이라고 간주하기 는 어렵지만 선행연구들에서는 말소리장애 아동의 발달력, 가족 력, 병력 등을 포함한 위험요인이 말소리장애 아동에게 미치는 영 향을 조사하고자 노력하였다. 위험요인은 말소리장애가 발현할 때 영향을 주거나 혹은 말소리장애 중증도를 악화시키거나 말 문제를 유지시킬 수 있기 때문이다. 따라서 말소리장애와 관련된 위험요인 을 파악하고 중재를 계획한다면 치료 효율성을 높일 수 있을 것이 다(Broomfield \& Dodd, 2004; Eadie et al., 2015; Fox, Dodd, \&
Howard, 2002).

다수의 연구를 종합하면 (1) 연령, (2) 성별, (3) 사회경제적요인 (socioeconomic status, SES), (4) 가족력, 형제 수와 같은 형제 변인, (5) 인지, (6) 언어 발달, (7) 학업 성취도, (8) 전반적인 운동 능력, (9) 구강-얼굴 운동 능력, (10) 혀 내밀기(tongue thrust), (11) 공갈 젖꼭 지 사용 같은 부적절한 빨기 습관, (12) 삼출성 중이염, (13) 말 지각 능력, (14) 말 산출 기관의 경미한 구조 문제, (15) 구강 감각을 말소 리장애와 연관된 위험요인으로 보았다(Bernthal, Bankson, \& Flipsen, 2017). 이 중 아동의 사례력과 관련된 위험요인 현황에 대해 자세히 조사한 Broomfield와 Dodd (2004)는 320명의 말소리장애 아동의 성별, SES, 초기 언어 발달, 초기 전반적 발달, 출생 전후 건강, 청력, 가족력, 섭식 및 구강 운동 문제, 이중언어, 가족 수, 행동 문제, 양육 문제에 대해 살펴보았다. 이들은 위험요인이 말소리장애에 부정적 인 영향을 미치는 기준을 제시하였다. 예를 들어, 첫 낱말 출현과 독 립 보행이 18 개월 이후에 나타났다면 언어 발달 및 전반적 발달이 지연된 것으로 간주하였다. 부모나 형제에게서 말-언어, 의사소통 
관련 문제가 있다는 가족력이 보고된 경우나 출생 전후로 한 달 이 상 입원을 하거나 빈번하게 입원한 경우 말소리장애에 부정적인 영 향을 미칠 수 있다고도 판단하였다. 연간 2회 이상 중이염을 않는 청력 변동 요인, 비위관(nasogastric tube)을 사용한 섭식이나 3세 이후에도 식사 시간이나 정해진 시간 이외에 습관적으로 젖병이나 공갈 젖꼭지를 사용하는 부적절한 섭식 및 구강운동도 위험요인으 로 보았다. 이 밖에 양육자가 염려하는 행동 문제를 동반하였거나 이중언어환경 노출, 학대나 방임 같은 우려사항이 있거나, 형제가 4 명을 넘는 경우도 말소리장애 발생에 영향을 끼칠 수 있는 위험요 인으로 지적하였다.

따라서 본 연구에서도 말소리장애 아동의 전반적인 발달력, 병 력, 성장 배경과 관련된 요인, 즉 말소리장애에 영향을 끼칠 수 있는 위험요인에 대해 조사할 필요성이 있다고 판단하였다. 위험요인 중 먼저 출산 전후 문제를 살펴보면, 출산 전후 병력은 말소리장애 뿐 아니라 대부분의 장애군에서 위험요인으로 지적되는 측정치이다. 특히 임신 중 감염, 조산, 저체중은 말-언어 발달에 부정적인 영향 을 미친다고 하며(Brown \& Edwards, 1989) 출산 전후 문제가 말소 리장애와 일반 아동을 예측할 수 있는 요인이라는 연구 결과도 있 다(Fox et al., 2002). 따라서 출생 전-중-후 문제가 말소리장애 하위 유형 간에도 차이가 있는지 살펴보아야 할 것이다.

삼출성 중이염은 중이강 내에 삼출액이 차있어 $15-20 \mathrm{~dB}$ 정도 전 도성 난청을 초래한다(Shim, Song, \& Jin, 2005). 따라서 생애 초기 3 년간 빈번하게 혹은 만성적으로 삼출성 중이염에 노출된 아동들 은 전도성 난청으로 인한 말 지각 능력에 영향을 받을 수 있다. 말 지각 능력은 이후 말-언어 발달에 중요한 영향을 끼치기 때문에 아 동에게 반복적이거나 만성적인 중이염 이력이 있다면 말소리장애 에 위험요인으로 작용할 수 있으므로 조사가 필요하다.

가정의 사회경제적 수준은 아동의 학습 환경을 간접적으로 나 타내는 요인이 될 수 있어 다수의 말-언어 연구에서 지속적으로 위 험요인으로 고려되고 연구되어왔다. 저소득층 아동의 음운인식 능 력이 중산층 아동에 비해 유의하게 낮았고(Ahn, Lee, Kim, Shin, \& Park, 2007), 문장 따라말하기 수행력이 유의하게 낮기도 하였다 (Balladares, Marshall, \& Griffiths, 2016). Broomfield와 Dodd (2004) 의 대단위 연구에서는 말소리장애 아동의 사회경제적 수준을 네 단계로 나누어 살펴보았을 때 통계적으로 유의한 차이는 나타나지 않았으나 조음장애 아동은 부유한 집단이 주를 이루었으며, 비일 관적 음운장애 집단은 사회경제적 수준이 가장 낮은 집단이 주를 이루었다. 따라서 우리나라 말소리장애 아동을 대상으로도 사회경 제적 수준을 살펴봄으로써 말소리 발달과 장애에 어느 정도 영향 을 끼치는지 살펴볼 필요가 있다.
아동이 공갈 젖꼭지나 엄지손가락, 젖병을 과도하게 빠는 습관 을 가지고 있으면 근기능 장애를 유발하거나 구강 인식 능력과 구 강 운동 능력이 감소된다는 연구 결과가 있다(Garliner, 1971). 따라 서 빨기는 제한적인 시간만 이루어질 것이 권고되기도 한다. 만약 24 개월 이후에 지속적인 빨기 습관을 가지고 있는 경우 말소리장 애에 위험요인으로 작용할 수 있다는 보고도 있다(Fox et al., 2002). 그러므로 말소리장애 아동에게 24 개월 이후에도 부적절한 빨기 습관이 남아있는지 확인해야 할 것이다.

가족력은 Broomfield와 Dodd (2004)의 연구에서 조사한 말소 리장애 전체 아동 중 $22 \%$ 에게서 보고되었다. 말소리장애 하위유형 별로 살펴보면 조음장애 아동은 $15.0 \%$, 음운지연 아동은 $20.0 \%$, 일관적 음운장애 아동은 $27.3 \%$, 비일관적 음운장애 아동은 $36.7 \%$ 에게서 말, 언어와 관련된 가족력이 보고되었다. 또한 Leweis와 Freebarin (1997)도 가족력이 있는 말소리장애 아동은 말소리장애 아 동 내에서도 특정한 집단을 형성하는 것 같은 양상을 보인다고 보 고하였다.

말소리장애 아동의 인지 능력에 대한 선행연구를 살펴보면, 말소 리장애 아동은 일반 아동과 인지 능력에 유의한 차이가 없으며 Dodd의 분류법으로 나눈 4 개의 하위유형 간에도 유의한 차이는 나타나지 않았다. 하지만 집단 평균치로 비교하면 일반 아동보다는 말소리장애 아동의 인지 능력이 더 낮았고, 말소리장애 아동 중에 서도 조음장애군은 일반 아동과 흡사하였으나, 일관적 음운장애 와 비일관적 음운장애의 인지 능력은 다소 낮아지는 경향성을 드 러냈다(Broomfield \& Dodd, 2004). 따라서 한국 말소리장애 아동 의 인지 능력에 대해 면밀히 조사할 필요가 있다.

선행연구를 종합하여 살펴보면 말소리장애 아동의 위험요인으 로 제안된 측정치는 성별, 사회경제적 지위, 생애 초기 언어 능력, 생 애 초기 전반적 발달, 가족력, 인지, 양육자의 교육 수준, 형제 수, 부 적절한 빨기 습관 등이 있다(Broomfield \& Dodd, 2004; Eadie et al., 2015; Fox et al., 2002). 사례력이 말소리장애 아동에게 미치는 영향을 종합하였을 때, 생애 초기 옹알이 빈도, 18 개월 이전 언어 발달 및 전반적 발달, 부적절한 공갈 젖꼭지 사용이 말소리장애 아 동에게 주의 깊게 살펴보아야 하는 위험요인이라 지적되며 말소리 장애 하위유형 간에도 유의한 차이가 있는 것으로 보고되었다. 하 지만 우리나라 말소리장애 아동에게 발달 특성과 관련된 사례력이 말소리장애 아동의 하위유형 감별 진단에 어느 정도 기여하는지는 검증되지 않았다. 말소리장애 여부와 지속성을 예측할 수 있는 위 험요인을 다각도로 탐색한다면 말소리장애 아동의 감별 진단 및 효과적인 중재법 도입에 도움이 될 것이다.

따라서 본 연구는 만 3-9세 말소리장애 아동을 대상으로 말소리 
장애 발현 및 지속 기간에 영향을 미친다고 보고되는 위험요인 현 황에 대해 조사하고 주성분분석을 통해 주요 말소리장애 위험요인 을 정리하고 말소리장애 하위유형별로 주요 위험요인 분포에 차이 가 있는지 알아보고자 한다.

\section{연구방법}

\section{대상자}

본 연구는 만 3-9세 말소리장애 아동 62명을 대상으로 하였다. 말 소리장애 아동은 아동용 발음평가(Assessment of Phonology and Articulation for Children, APAC; Kim, Pae, \& Park, 2007)를 실시 하였을 때 일반 자음정확도 기준으로 백분위수가 $16 \%$ ile (-1 SD) 이 하에 속하며, 주 양육자로부터 감각과 신경학적 문제와 연관된 동 반 장애를 진단받지 않았다고 보고된 아동이었다. 아동의 생활연 령이 6세 6개월 이상일 경우는 APAC 규준이 제공되지 않으므로 원점수가 3점 이상인 경우를 말소리장애 아동으로 간주하였다(So \& Ha, 2020).

대상자는 방음실이나 독립된 공간처럼 소음이 차단된 공간에서 $500,1,000,2,000,4,000 \mathrm{~Hz}$ 가청 주파수에 대해 순음 청력검사를 실시하였을 때 청력 역치가 모두 $20 \mathrm{~dB} \mathrm{HL}$ 이하로 정상 청력이었다. 또한 대상자의 한국 웩슬러 유아지능검사 4판(Korean-Wechsler Preschool and primary scale of Intelligence-Fourth Edition, KWPPSI-IV; Park, Lee, \& Ahn, 2015)과 한국 비언어 지능검사-제2 판(Korean Comprehensive Test of Nonverbal Intelligence-second edition, K-CTONI-2; Park, 2014)의 비언어성 인지 지수가 75 이상 인 아동만 포함하였다.

말소리장애 하위유형 분류는 Dodd의 감별진단모델(2014)을 참 조한 $\mathrm{Pi}$ 와 $\mathrm{Ha}$ (2020)의 기준을 적용하였다. 감별 진단 모델은 아동 의 언어학적 증상인 음운 오류패턴과 낱말 산출 일관성에 따라 말 소리장애 아동을 조음장애(articulation disorder, $\mathrm{AD}$ ), 음운지연 (phonological delay, $\mathrm{PD}$ ), 일관적 음운장애(consistent phonological disorder, $\mathrm{CPD}$ ), 비일관적 음운장애(inconsistent phonological disorder, IPD)로 분류하였다.

조음장애 아동은/시나/리처럼 특정 한 두개 음소에서 대치나 왜곡 오류를 보이는 아동을 이른다(Dodd, 2005). 아동의 오류패턴 이 여러 개지만 목표 음소가 한두개인 경우도 마찬가지로 조음장 애 집단으로 보았다(예: 아동의 오류패턴이 파열음화, 파찰음화, 치 간음화로 나타났지만 목표 음소가 / ㅅ/, / ㅆ/에 한정된 경우). 음운 지연 아동은 현재 연령에서는 $10 \%$ 미만의 아동에게서 관찰되지만 또래보다 어린 연령의 아동에게서 $10 \%$ 이상 관찰되는 오류패턴 즉,
발달적인 오류패턴만을 보이는 아동으로 분류하였다. 일관적인 음 운장애 아동은 발달적인 오류패턴과 비발달적인 오류패턴을 모두 보이며 말 산출이 일관적인 아동을 말한다. 비일관적인 음운장애 아동은 오류패턴과 무관하게 낱말 산출 일관성 기준에 도달하지 못한 아동을 분류하였다.

말소리장애 아동의 산출 일관성은 한국 조음음운 프로파일 (Korean Articulation Phonology Profile, K-APP; Ha, Kim, Seo, \& $\mathrm{Pi}, 2021)$ 의 '낱말 일관성 검사'를 이용하여 정상적인 변이성과 병리 적인 비일관성을 구분하였다. 따라서 K-APP 낱말 일관성 검사 점 수가 30점 이상인 경우 말 산출이 일관적이라고 보았고 30점 미만 인 경우 말 산출이 비일관적이라고 판단하였다. 말소리장애 아동의 하위유형 및 연령별 분포 비율은 Table 1에 제시하였다.

\section{연구절차}

본 연구 절차는 한림대학교 생명윤리위원회의 승인(HIRB-2018021)을 받아 진행되었으며 모든 대상자의 보호자에게 연구 과정에 대해 설명한 후 연구참여 동의서에 서명을 받았다.

본 연구의 자료 수집은 검사자가 아동의 가정이나 교육기관(어린 이집, 유치원, 지역아동센터, 언어치료실)에 방문하거나 아동이 연 구자가 상주하는 언어치료실에 방문하여 진행하였다. 검사자는 주 양육자와 면담지 작성을 통해 아동의 성별, 사회경제적 수준, 가족 력, 임신 및 출산과정 중 문제, 출생 직후 문제, 청력 변동요인, 설소 대 단축증 수술 경험, 부적절한 빨기 행동, 생애 초기 말-언어 발달, 생애 초기 전반적 발달, 이중언어환경 노출, 치료력에 대한 정보를 수집하였다. 양육자 면담 시간은 약 15 분간 진행되었다.

또한 아동의 인지 능력을 파악하기 위해 학령 전기 말소리장애 아동에게는 한국 웩슬러 유아지능검사 4판(K-WPPSI-IV; Park et al., 2015) 중에서 비구어 인지 평가와 관련된 소검사를 실시하였다. 학령기 아동에게는 한국 비언어 지능검사-제2판(K-CTONI-2; Park, 2014)을 실시하였다.

언어재활사 1 급 자격증 소지자인 검사자는 K-WPPSI-IV 검사 실

Table 1. Ratio by subtypes of children with SSDs

\begin{tabular}{lrcccc}
\hline Age groups & $\mathrm{N}$ & $\mathrm{AD}(\mathrm{N}=12)$ & $\mathrm{PD}(\mathrm{N}=29)$ & $\mathrm{CPD}(\mathrm{N}=9)$ & $\operatorname{IPD}(\mathrm{N}=12)$ \\
\hline $3 ; 0-3 ; 11$ & 9 & 0.00 & 22.22 & 11.11 & 66.67 \\
$4 ; 0-4 ; 11$ & 9 & 0.00 & 66.67 & 11.11 & 22.22 \\
$5 ; 0-5 ; 11$ & 16 & 6.25 & 56.25 & 25.00 & 12.50 \\
$6 ; 0-6 ; 11$ & 13 & 46.15 & 38.46 & 7.69 & 7.69 \\
$7 ; 0-9 ; 11$ & 15 & 33.33 & 46.67 & 13.33 & 6.67 \\
Total & 62 & 19.35 & 46.77 & 14.52 & 19.35 \\
\hline
\end{tabular}

$\mathrm{AD}=$ articulation disorder; $\mathrm{PD}=$ phonological delay; $\mathrm{CPD}=$ consistent phonological disorder; IPD = inconsistent phonological disorder. 
시 이전에 평가도구의 실시 및 해석 방법을 숙지하기 위해 'K-WPPSI-IV 한국 웩슬러 유아지능검사 워크숍 초급/중급' 교육과정을 이 수하였다(수료 번호 no. 18-EC180625142911-12-13983호).

\section{연구도구 및 자료분석}

본 연구는 말소리장애와 관련된 위험요인을 조사하기 위해 주 양육자와 인터뷰 및 설문지 작성을 실시하였다. 조사 과정에서 사 용한 설문지는 Fox 등(2002) 연구를 참조 및 보완하여 제작하였다. 아동의 위험요인은 체계적인 문헌조사를 통해 1) 성별, 2) 인지, 3) 임신 및 출산 중 문제, 4) 출생 직후 문제, 5) 평가 당시 삼출성 중이 염, 6) 반복적인 중이염, 7) 만성 중이염, 8) 고막 환기관 삽입술, 9) 설 소대 수술, 10) 부적절한 빨기 습관, 11) 가정 내 소득 수준, 12) 주양 육자의 학력, 13) 월 교육비, 14) 사회경제적 수준 종합, 15) 이중언어 환경, 16) 가족력, 17) 첫 낱말 출현 시기, 18) 언어지연, 19) 스스로 걸은 시기, 20) 전반적 발달 지연, 21) 언어 치료력, 22) 타 영역 치료 력 항목으로 나누어 조사하였다(Broomfield \& Dodd, 2004; Eadie et al., 2015; Fox et al., 2002). 또한 위험요인은 구체적인 문헌조사를 통해 수립한 기준으로 분석하였다.

인지

말소리장애 아동은 약 $50 \%$ 가량 언어지연이나 언어장애를 동반 한다는 선행연구들을 참조하여, 인지 능력을 조사할 때 아동의 언 어 능력을 최대한 배제하고자 하였다. 따라서 비구어인지 검사를 실시하여 산출된 비언어성 지능(nonverbal intelligence, NVI) 지표 를 사용하여 아동의 인지 능력을 조사하였다.

\section{출생 전-중-후 문제}

임신 및 출산 과정 중 문제 여부는 Fox 등(2002)의 연구를 참고 및 보완하여 조사하였다. 임신 과정 중 문제는 산모의 극심한 스트 레스, 약물 노출, 전자간증/자간전증(Pre-eclampsia) 등과 같은 임 신 중 질병이 있었는지 폐쇄형 질문으로 조사한 뒤, 위 질병에 해당 하지 않는 경우 개방형 질문으로 작성자가 직접 질병명을 기재할 수 있도록 하였다.

출산 과정 중 문제는 37주 미만에 태어난 미숙아/조산아, 출생 당 시 체중이 2,500 g 미만인 저체중아에 해당하는지 먼저 조사하였 고, 탯줄 탈출증, 겸자 분만, 태반 조기 박리가 있었는지 폐쇄형 질 문으로 조사하였다. 위 경우에 해당하지 않은 출산 과정 중 문제가 있었을 시 개방형 질문으로 작성자가 직접 출산 과정 중 문제를 기 재할 수 있도록 하였다.

출생 직후 문제 여부는 아동 출생 이후 1 개월 이내에 선천성 감
염 질환(예: 톡소플라즈마 감염증, 거대세포바이러스 감염증 등), 신생아 뇌출혈, 신생아 중환자실에 입원을 요하는 수준의 고열, 경 기, 신생아 황달이 있었는지 조사하였다.

\section{청력 변동 요인}

청력 변동 요인은 Shim 등(2005)의 연구를 참조 및 보완하여 현 재 삼출성 중이염 유무, 반복적 삼출성 중이염 경험 여부, 만성 삼 출성 중이염 경험 여부, 고막 환기관 삽입술 경험 여부를 살펴보았 다. 현재 삼출성 중이염 유무는 평가 당시 아동의 중이강 내에 삼출 액이 차 있는지 조사하였다. 반복적 삼출성 중이염 경험 여부는 생 후 3 년 이내에 연간 2 회 이상 잦은 삼출성 중이염을 않았는지 질문 하였다. 만성 삼출성 중이염은 삼출성 중이염 이환 기간을 조사하 였으며, 삼출성 중이염이 3주 이상 지속되었다고 보고된 경우를 만 성 삼출성 중이염으로 간주하였다. 고막 환기관(tympanostomy tube) 삽입술은 삼출성 중이염을 반복적, 만성적으로 않는 환자에 게 삼출액 배출과 중이의 환기를 목적으로 고막을 절개하여 작은 튜브를 삽입하는 외과적 처치이다. 아동의 주 양육자에게 아동이 고막 환기관 삽입술을 받은 경험이 있는지 폐쇄형 질문으로 조사 하였다.

\section{설소대 수술 여부}

설소대 단축증(tonge tie) 수술은 혀와 구강저를 연결하는 설소 대가 단축되어 혀 운동에 제약을 주는 경우 실시하는 수술이다. 해 당 아동이 평가 시기 이전에 설소대 단축증 수술을 받은 이력이 있 는지조사하였다.

\section{부적절한 빨기 습관(sucking habit)}

아동에게 부적절한 빨기 습관이 있었는지 여부는 Fox 등(2002) 의 연구를 참고 및 보완하여 조사하였다. 선행 연구에서는 공갈 젖 꼭지나 손가락, 젖병 등을 과용하였을 때 근기능장애나 구강운동 능력 감소로 이어진다는 점을 지적하였으며 말소리장애 아동은 24 개월 이후에도 젖병, 엄지 손가락, 공갈 젖꼭지의 사용이 일반 아동 에 비해서 높다는 점을 시사하였다. 따라서 본 연구에서도 생후 24 개월 이후에 특정 시간대(예: 수유 시간)에 한정적인 사용을 제외 한 젖병 사용이 있었는지, 또한 생후 24 개월 이후에도 엄지 손가락 빨기나 공갈 젖꼭지 사용이 지속되었는지 조사하였다.

\section{사회경제적 수준(Socioeconomic status, SES)}

아동의 양육 환경을 조사하기 위한 요인으로 가정 및 부모의 사 회경제적 수준을 조사하였다. 사회경제적 수준은 So와 $\mathrm{Ha} \mathrm{(2020)}$ 
를 참조하여 가족 구성원 수 대비 가정 내 소득, 주 양육자의 최종 학력, 해당 자녀에게 사용하는 한 달 교육비를 조사하였다.

가정 내 소득은 보건복지부가 제시한 2018-2020년도 중위소득 및 생계급여 선정 기준(www.mohw.go.kr)을 바탕으로 일반 가정 과 저소득 가정으로 나누어 살펴보았다. 저소득 가정은 부모의 월 소득이 보건복지부가 지정한 가구 수 대비 가정의 소득 인정액이 중위 소득의 $50 \%$ 이하인 차상위계층 이하를 포함하였다. 일반 가 정은 중위소득 $50 \%$ 를 초과하는 가정으로 보았다.

주 양육자의 최종 학력은 Kim과 Kim (2009) 연구를 참조 및 보 완하여 고등학교 졸업 이하, 전문대학교 및 대학교 중퇴, 전문대 졸 업, 대학교 졸업, 대학원 졸업의 5 개 범주로 나누어 조사하였다.

해당 자녀에게 사용하는 한 달 교육비는 아동 양육과정에 필요 한 식비, 피복비 등을 제외한 뒤 도서 구입, 사교육, 재활 서비스 등 에 지출하는 비용을 조사하였다. 범주는 0-10만 원, 11-20만 원, 21-30만 원, 31-40만 원, 41 만 원 이상으로 분류하였다.

그 뒤 가정 내 소득과 주 양육자의 최종 학력, 아동 교육비를 모 아 사회경제적 수준을 종합하였다. 가정 내 소득은 정상 가정인 경 우 1 점, 저소득 가정인 경우 0 점을 부여하였고, 주 양육자의 학력은 대학원 및 대학 졸업인 경우 2점, 전문대 졸업이나 전문대학교 및 대학교 중퇴면 1점, 고등학교 졸업 이하는 0 점을 부여하였다. 해당 자녀의 월 교육비는 31 만 원 이상인 경우 1 점, 30 만 원 이하인 경우 0 점을 부여하였다. 세 조사 항목을 합산하여 0 점인 경우 '매우 낮 음, 1점인 경우 ‘낮음', 2점인 경우 ‘보통', 3점인 경우 ‘높음, 4점인 경 우 ‘매우 높음'으로 가정의 사회경제적 수준을 분류하였다.

\section{가족력}

가족력은 해당 아동의 직계 및 방계 가족에게서 말-언어 문제를 동반했던 가족 구성원이 있는지 조사하였다(Fox et al., 2002).

\section{이중언어환경 노출}

이중언어환경은 다문화가정 아동이거나 아동이 1년 이상 해외 거주한 이력이 있는 경우를 중심으로 조사하였다. 먼저, 다문화가 정은 아동의 양육자 중 한 명 이상이 한국어가 모국어가 아닌 경우 로 정의하였다. 아울러 아동이 1 년 이상 해외에 거주하며 2 개 이상 언어를 사용하거나, 한국 거주 시에도 1 년 이상 가정 내에서 한국 어 이외의 언어를 주로 사용하였는지 조사하였다.

\section{생애 초기 말-언어 발달}

해당 아동의 생애 초기 말-언어 발달은 첫 낱말 시기와 만 2 세 경 언어 발달 지연 여부를 조사하였다. 첫 낱말은 아동이 자발적이고
일관적으로 사용하는 단어(예: 엄마, 아빠 등)를 이르며 일반 아동 의 첫 낱말 출현 시기는 평균적으로 12 개월 전후이다. 아동에게서 자발적이고 일관적으로 사용한 단어가 18 개월 이후에 나타났다고 보고되는 경우는 첫 낱말 출현이 지연, 이전에 나타난 경우는 정상 발달 범주로 보았다(Broomfield \& Dodd, 2004).

아동의 언어 발달 지연 여부는 Fox 등(2002)의 연구에서 문장 조 합 시기를 개방형 질문으로 작성하게 하였을 때 양육자가 보고한 문장 조합 시기에 대한 편차가 크고 정확하지 않아 신뢰도가 낮았 다는 점을 반영하여 연구자와 면담을 면밀하게 진행하였다. 먼저 주 양육자에게 ‘말 늦은 아동'(Paul, 1991; Paul \& Jennings, 1992; Rescorla, 1989; Thal \& Bates, 1988)에 대한 정의를 정확하게 제시 하였다. 다시 말하자면, 해당 아동이 18-23개월에 명료하게 발음하 는 단어의 수가 10 개 이하였거나, 18-30개월에 표현 어휘가 50 개 미 만이었거나, 24 개월 이후에도 낱말을 조합해서 사용하는 게 어려 웠는지 질문하였다. 추가적으로 24 개월 전후 실시하는 4 차 영유아 건강검진을 받은 경우에 언어 발달 영역에 대해 추적 및 심화 검사 를 권고받았는지 조사하였다. 위 경우에 해당하는 아동은 언어 발 달이 지연되었다고간주하였다.

\section{생애 초기 전반적 발달}

해당 아동의 생애 초기 전반적 발달 특성은 말-언어 영역을 제외 한 신체, 정서, 인지 발달을 중심으로 살펴보았다. 먼저 아동이 스스 로 걸은 시기를 조사하였다. 일반 아동은 12 개월 전후에 물체에 의 지하지 않고 스스로 걷기가 가능하다. 만약 대상 아동이 스스로 걸 은 시기가 18 개월 이후에 나타났다고 보고되는 경우는 스스로 걸 은 시기가 지연된 것으로 간주하였다(Broomfield \& Dodd, 2004).

아동의 전반적 발달 지연 여부는 주 양육자가 아동이 생후 2 세 경에 또래와 비교하였을 때 신체, 정서, 인지 면에서 지연되었다고 느꼈는지, 보육 기관 교사에게서 전반적인 발달 영역에 대해 평가 를 권고받거나 혹은 영유아 건강검진에서 언어 발달 영역 이외의 영역에 대해 추적 및 심화 검사를 권고받았는지 조사하였다. 위 경 우에 해당하는 아동은 생애 초기 전반적인 발달이 지연되었다고 간주하였다.

\section{언어치료 및 타 영역 치료력}

아동의 치료력은 크게 언어 치료력과 타 영역 치료력으로 구분 하여 조사하였다. 언어 치료력은 아동의 과거의 특정 시점에 언어 재활서비스를 받았거나 혹은 과거부터 현재까지 언어재활서비스 를 받았다고 보고한 경우 언어 치료력이 있다고 보았다. 언어재활서 비스를 전혀 받지 않은 아동만 언어 치료력이 없다고 간주하였다. 
타 영역 치료력은 아동이 과거의 한 시점이나 과거부터 현재까지 언어 영역을 제외한 발달 영역에서 재활 서비스를 받았거나 받고 있는지 조사하였다. 면담자가 타 영역 치료력이 있다고 응답한 경우 물리, 작업, 놀이, 심리, 인지치료와 같은 예를 제시하고 어떤 영역에 서치료 경험이 있는지 서면 작성하도록 요청하였다.

\section{통계 분석}

통계 처리는 SPSS version 25.0 (IBM corp., Armonk, NY, USA) 을 이용하였다. 본 연구에서 조사한 말소리장애 위험요인 측정치 수가 많아 측정치를 축소하기 위해 주성분분석(principal component analysis, PCA)을 선행하였다. 위험요인 항목 22개 중 모든 말 소리장애 아동에게서 출현하지 않았다고 보고된 항목, 다시 말하 면 전체 항목이 0 으로 조사된 '출생 직후 문제 유무', ‘현재 삼출성 중이염 유무, '고막 환기관 삽입술' 실시 유무는 표준 편차가 0으로 분석을 실시할수 없는 측정치라주성분분석에서 제외되었다. 위험 요인 측정치들이 주성분분석을 하기 적합한 지 알아보기 위해 $\mathrm{KMO}$ 척도(Kaiser-Meyer-Olkin measure of sampling adequacy) 와 Bartlett의 구형성 검정 결과를 살펴보았다. $\mathrm{KMO}$ 척도는 표본 적절성 측정치로 1 에 가까울수록 요인을 분석하기에 적합한 자료 임을 의미하며, 일반적으로 .5이상이면 주성분분석하기에 적절하 다고 여겨진다(Kaiser, 1974). Bartlett의 구형성 검정은 변수들 간의 상관이 0 인지를 검정하는 것으로 구형성 검정 통계치가 크고 유의 확률이 .05 이하로 작을수록 요인분석에 적합하다는 뜻을 나타내 는 통계치이다. 주성분분석을 실시하였을 때, 요인 적재량이 .3 미 만이거나 어느 요인에도 속하지 않는 측정치는 최종적으로 주성분 분석을 실시할 때 배제하였다. 요인 회전 방식은 요인 간 상관관계 가 있다고 가정하는 사각회전법인 프로멕스(promax) 회전법을 사 용하였다.

다음으로 3-9세 말소리장애 아동을 Dodd (2014)의 감별진단모 델에서 제시한 하위유형으로 분류하였을 때 조사한 위험요인에서 차이가 나타나는지 살펴보기 위해 카이제곱 검정을 실시하였다.

\section{연구결과}

\section{성분분석을 통한 주요 말소리장애 위험요인}

말소리장애 아동의 위험요인 현황을 살펴보기 이전에 위험요인 측정치 22개 항목에 대해 주성분분석을 실시하여 주된 위험요인 을 축약하고자 하였다. 말소리장애 62 명 아동의 설문조사 중 주양 육자의 학력과 자녀 월 교육비에 대해 미응답된 6세 아동 3명, 7세 아동 2 명, 8 세 아동 1 명이 분석에서 제외되었다. 따라서 말소리장애
아동 56 명에 대해 위험요인에 해당하는 변수의 주성분분석을 선 행하였다.

위험요인 측면 척도는 1) 성별, 2) 인지, 3) 임신 및 출산중 문제, 4) 출생 직후 문제, 5) 평가 당시 삼출성 중이염, 6) 반복적인 중이염, 7) 만성 중이염, 8) 고막 환기관 삽입술, 9) 설소대 수술, 10) 부적절한 빨기 습관, 11) 가정 내 소득 수준, 12) 주 양육자의 학력, 13) 월 교육 비, 14) 사회경제적 수준 종합, 15) 이중언어환경, 16) 가족력, 17) 첫 낱말 출현 시기, 18) 언어지연, 19) 스스로 걸은 시기, 20) 전반적 발 달 지연, 21) 언어 치료력, 22) 타 영역 치료력 항목을 조사하였다. 위 험요인 측면을 축소하기 위해, 위험요인 측면이 어떤 성분으로 이루 어져 있는지 주성분분석을 실시하고자 하였다. 이 중 모든 말소리 장애 아동에게서 출현하지 않았다고 보고된, 즉 전체 항목이 0 으 로 표기된 출생 직후 문제, 현재 삼출성 중이염, 고막 환기관 삽입술 실시 유무는 표준 편차가 0 으로 분석을 실시할 수 없는 측정치이므 로 주성분분석에서 제외되었다.

일차적으로 위험요인 19 개 항목에 대해 주성분분석을 실시했을 때 $\mathrm{KMO}$ 척도는 .475였으며, 사회경제적 수준 종합지표, 자녀의 월 교육비, 설소대 수술 여부, 이중언어환경 노출 측정치는 어느 요인 에서도 .3 이상 요인 적재량을 갖지 못했다. 또한 인지 측정치는 어 떤 요인에도 확실하게 포함되지 않아서(double loading) 최종적으 로 5 개항목은 주성분분석 변수에서 제외하였다.

따라서 위험요인 22 가지 항목 중 최종적으로 14 개 위험요인을 바 탕으로 요인분석의 적절성을 검증하였다. 14 개 위험요인은 1) 성별, 2) 가정 내 소득수준, 3) 주 양육자의 학력, 4) 가족력 유무, 5) 임신 및 출산 중 문제, 6) 반복적 삼출성 중이염, 7) 만성 삼출성 중이염, 8) 부적절한 빨기 습관, 9) 첫 낱말 출현 시기, 10) 생애 초기 언어지 연, 11) 스스로 걷기 시기, 12) 생애 초기 전반적 발달 지연, 13) 언어 치료력, 14) 타 영역 치료력이 해당하였다. 위험요인 14개 평가 항목 의 $\mathrm{KMO}$ 척도는 .544 으로 나타나 적정 수준인 .5 을 넘었으며 Bartlett 의 구형성 검정 결과도 유의하게 나타났다 $\left(\chi^{2}\left({ }^{21)}=190.480, p<.001\right)\right.$. 따라서 위험요인 측면에 대해 주성분분석 방법이 적합함을 알 수 있었다.

위험요인 항목 14 개에 대해 Kaiser 정규성을 갖는 프로멕스 방법 으로 요인회전한 주성분분석을 실시하였을 때 소검사 별 요인 적재 량을 Table 2에 제시하였다. 요인 1은 전반적 발달 지연, 첫 낱말 출 현 시기, 언어 치료력, 타 영역 치료력, 스스로 걷기 시기, 언어지연 유무가 포함되어 ‘언어 및 신체 발달'로 명명하였다. 요인 2는 임신 및 출산 과정 중 문제, 성별, 부적절한 빨기 습관이 포함되었다. 따 라서 ‘성별 및 생애 초기 문제’라고 명명하였다. 요인 3은 반복적 삼 출성 중이염과 만성 삼출성 중이염 측정치가 포함되었다. 따라서 
Table 2. Factor loading by measurements using the promax rotation

\begin{tabular}{|c|c|c|c|c|c|}
\hline & $\begin{array}{c}\text { Risk factor } 1 \\
\text { language and gross } \\
\text { motor development }\end{array}$ & $\begin{array}{c}\text { Risk factor } 2 \\
\text { gender and early } \\
\text { development }\end{array}$ & $\begin{array}{l}\text { Risk factor } 3 \\
\text { OME }\end{array}$ & $\begin{array}{l}\text { Risk factor } 4 \\
\text { SES }\end{array}$ & $\begin{array}{l}\text { Risk factor } 5 \\
\text { family history }\end{array}$ \\
\hline General development & 0.868 & 0.110 & -0.091 & 0.089 & -0.214 \\
\hline First word & 0.724 & -0.135 & -0.088 & -0.029 & 0.272 \\
\hline History of speech language therapy & 0.714 & 0.385 & 0.247 & 0.017 & 0.105 \\
\hline History of therapy other than speech-language therapy & 0.676 & -0.060 & 0.067 & -0.265 & 0.207 \\
\hline Self-walking & 0.527 & -0.205 & -0.451 & 0.064 & -0.175 \\
\hline Language delay & 0.480 & -0.281 & 0.360 & 0.068 & -0.037 \\
\hline Birth history & 0.089 & 0.774 & -0.101 & 0.100 & -0.399 \\
\hline Gender & -0.008 & 0.641 & 0.173 & -0.236 & -0.071 \\
\hline Sucking habit & -0.021 & 0.640 & -0.131 & 0.090 & 0.159 \\
\hline Recurrent OME & 0.131 & 0.082 & 0.888 & 0.088 & 0.003 \\
\hline Chronic OME & -0.113 & -0.237 & 0.683 & 0.065 & -0.247 \\
\hline Income & 0.020 & -0.214 & 0.155 & 0.804 & -0.076 \\
\hline Educational background of caregiver & -0.098 & 0.200 & 0.013 & 0.802 & 0.319 \\
\hline Family history & 0.112 & -0.116 & -0.111 & 0.130 & 0.920 \\
\hline
\end{tabular}

Table 3. First word and language development delay in children with SSDs

\begin{tabular}{lcc}
\hline & First word $(\%)$ & $\begin{array}{c}\text { Language development delay } \\
\text { at the age of } 2(\%)\end{array}$ \\
\hline $\mathrm{AD}(\mathrm{N}=12)$ & $0(0.0)$ & $7(58.3)$ \\
$\mathrm{PD}(\mathrm{N}=29)$ & $6(20.7)$ & $18(62.1)$ \\
$\mathrm{CPD}(\mathrm{N}=9)$ & $2(22.2)$ & $6(66.7)$ \\
$\mathrm{IPD}(\mathrm{N}=12)$ & $3(25.0)$ & $9(75.0)$ \\
Total $(\mathrm{N}=62)$ & $11(17.7)$ & $40(64.5)$ \\
\hline
\end{tabular}

$\mathrm{AD}=$ articulation disorder; $\mathrm{PD}=$ phonological delay; $\mathrm{CPD}=$ consistent phonological disorder; $\mathrm{IPD}=$ inconsistent phonological disorder.

'삼출성 중이염' 요인으로 명명하였다. 요인 4는 가정 내 소득과 주 양육자의 학력에 대한 측정치로 'SES'로 명명하였다. 요인 5 는 가족 력 유무 변수만 포함되어 변수를 그대로 사용하였다.

\section{말소리장애 하위유형별 위험요인 동반 비율}

주성분분석을 통해 나타난 요인 순으로 말소리장애 아동의 위 험요인 동반 비율과 하위유형별 유의한 차이가 나타나는지 살펴보 았다.

\section{언어 및 신체 발달}

첫 번째로 아동의 언어 발달을 조사하였다. 언어 발달은 첫 낱말 출현시기와 24개월경 언어 발달 지연 여부로 나누어 살펴보았다. 말소리장애 아동의 하위유형별 첫 낱말 및 언어 발달 지연 여부는 Table 3과 같다.

말소리장애 아동 중 정상적으로 첫 낱말이 출현한 경우는 $82.3 \%$, 첫 낱말 출현이 18 개월 이후로 지연된 경우는 $17.7 \%$ 였다. 말소리장
Table 4. Self-walking and general developmental delay in children with SSDs

\begin{tabular}{lcc}
\hline & Self-walking $(\%)$ & $\begin{array}{c}\text { General development delay } \\
\text { at the age of } 2(\%)\end{array}$ \\
\hline$A D(N=12)$ & $1(8.3)$ & $0(0.0)$ \\
$P D(N=29)$ & $5(17.2)$ & $13(44.8)$ \\
$C P D(N=9)$ & $2(22.2)$ & $3(33.3)$ \\
IPD (N=12) & $1(8.3)$ & $1(8.3)$ \\
Total $(N=62)$ & $9(14.5)$ & $17(27.4)$ \\
\hline
\end{tabular}

$\mathrm{AD}=$ articulation disorder; $\mathrm{PD}=$ phonological delay; $\mathrm{CPD}=$ consistent phonological disorder; $\mathrm{IPD}=$ inconsistent phonological disorder.

애 하위유형별로 나누어 살펴보면, 첫 낱말이 18 개월 이후로 늦게 나타난 아동은 조음장애 $0.0 \%$, 음운지연 $20.7 \%$, 일관적 음운장애 $22.2 \%$, 비일관적 음운장애 $25.0 \%$ 로 조사되었다.

말소리장애 아동 중 만 2 세 경에 언어 발달이 정상 수준이었다고 보고된 아동은 $35.5 \%$, 지연되었다고 보고된 아동은 $64.5 \%$ 였다. 말 소리장애 하위유형별로 나누어 살펴보면, 2 세 경 언어 발달이 지연 되었다고 보고된 아동은 조음장애 $58.3 \%$, 음운지연 $62.1 \%$, 일관적 음운장애 $66.7 \%$, 비일관적 음운장애 $75.0 \%$ 로 조사되었다.

말소리장애 하위유형에 따라 언어 발달에 유의한 차이가 있는지 알아보기 위해 카이제곱 검정을 실시한 결과, 말소리장애 하위유 형 간 첫 낱말 출현 시기 $\left(\chi_{(3)}^{2}=3.318, p=.345\right)$ 와 2 세 경 언어 발달 지연 $\left(\chi^{2}(3)=.871, p=.833\right)$ 에 유의한 차이가 나타나지 않았다.

두 번째로 말소리장애 아동의 전반적 발달 측면을 조사하였다. 전반적 발달은 스스로 걷기 시작한 시기와 24 개월경 전반적 발달 지연 여부로 살펴보았다. 말소리장애 아동의 스스로 걷기 및 전반 적 발달 지연 여부는 Table 4 와 같다. 
말소리장애 아동 중 스스로 걸은 시기가 18 개월 이후로 지연된 경우는 $14.5 \%$ 였다. 말소리장애 하위유형별로 나누어 살펴보면, 스 스로 걸은 시기가 18 개월 이후인 아동은 조음장애 $8.3 \%$, 음운지연 $17.2 \%$, 일관적 음운장애 $22.2 \%$, 비일관적 음운장애 $8.3 \%$ 로 조사되 었다.

말소리장애 아동 중 만 2 세 경에 전반적 발달이 지연되었다고 보 고된 아동은 $27.4 \%$ 였다. 말소리장애 하위유형별로 나누어 살펴보 면, 2 세 경 전반적 발달이 지연되었다고 보고된 아동은 조음장애 $0.0 \%$, 음운지연 $44.8 \%$, 일관적 음운장애 $33.3 \%$, 비일관적 음운장 애 $8.3 \%$ 로 조사되었다.

말소리장애 하위유형에 따라 전반적 발달에 유의한 차이가 있는 지 알아보기 위해 카이제곱 검정을 실시한 결과, 말소리장애 하위 유형 간 스스로 걸은 시기에 유의한 차이는 나타나지 않았으나 $\left(\chi_{(3)}^{2}=1.344, p=.719\right) 2$ 세 경 전반적 발달 지연 여부에서는 유의한 차이가 나타났다 $\left(\chi^{2}(3)=11.304, p=.010\right)$.

세 번째로, 말소리장애 아동의 언어 치료력과 타 영역 치료력에 대해 조사하였다. 말소리장애 아동의 하위유형별 언어 치료력 및 타 영역 치료력 유무는 Table 5에 제시하였다. 말소리장애 아동 중 언어 치료력이 있는 아동은 $38.7 \%$ 로 조사되었다. 말소리장애 하위 유형별로 나누어 살펴보면, 언어 치료력이 있는 아동은 조음장애 $16.7 \%$, 음운지연 $44.8 \%$, 일관적 음운장애 $33.3 \%$, 비일관적 음운장 애 $50.0 \%$ 였다.

말소리장애 아동 중 타 영역 치료력이 있는 아동은 $17.7 \%$ 로 조사 되었다. 말소리장애 하위유형별로 나누어 살펴보면, 타 영역 치료력 이 있는 아동은 조음장애 $8.3 \%$, 음운지연 $17.2 \%$, 일관적 음운장애 $44.4 \%$, 비일관적 음운장애 $8.3 \%$ 로 조사되었다. 언어 영역을 제외 한 재활서비스를 받았거나 받은 경험이 있다고 보고된 말소리장애 아동 11 명 사례를 자세히 살펴보면, 아동이 서비스 받은 재활치료 영역은 놀이치료(5명), 인지치료(4명), 심리상담(3명), 미술치료(2 명), 감각 통합 치료(1명) 순으로 나타났다(복수응답 가능).

말소리장애 하위유형에 따라 치료 경험에 차이가 있는지 알아보

Table 5. Therapy history for children with SSDs

\begin{tabular}{lcc}
\hline & $\begin{array}{c}\text { History of speech language } \\
\text { therapy (\%) }\end{array}$ & $\begin{array}{c}\text { History of therapy except } \\
\text { speech language therapy }(\%)\end{array}$ \\
\hline $\mathrm{AD}(\mathrm{N}=12)$ & $2(16.7)$ & $1(8.3)$ \\
$\mathrm{PD}(\mathrm{N}=29)$ & $13(44.8)$ & $5(17.2)$ \\
$\mathrm{CPD}(\mathrm{N}=9)$ & $3(33.3)$ & $4(44.4)$ \\
$\mathrm{IPD}(\mathrm{N}=12)$ & $6(50.0)$ & $1(8.3)$ \\
Total $(\mathrm{N}=62)$ & $24(38.7)$ & $11(17.7)$ \\
\hline
\end{tabular}

$\mathrm{AD}=$ articulation disorder; $\mathrm{PD}=$ phonological delay; $\mathrm{CPD}=$ consistent phonological disorder; $\mathrm{IPD}=$ inconsistent phonological disorder.
기 위해 카이제곱 검정을 실시한 결과, 말소리장애 하위유형 간 언 어치료 경험 $\left(\chi^{2}(3)=3.669, p=.299\right)$ 과 타 영역 치료 경험 $\left(\chi^{2}{ }_{(3)}=5.858\right.$, $p=.119)$ 에 유의한 차이는 나타나지 않았다.

\section{성별 및 생애 초기 문제}

먼저, 3-9세 말소리장애 아동의 하위유형별로 성비를 조사하였 다. 전체 말소리장애 아동 중 남자는 $67.7 \%$, 여자는 $32.3 \%$ 로 성비 는 약 2:1 정도로 나타났다. 말소리장애 하위유형별로 나누어 살펴 보면, 조음장애와 비일관적 음운장애 집단은 남자가 $75.0 \%$, 여자 가 $25.0 \%$ 로 $3: 1$ 의 성비를 보였다. 음운지연 집단은 남자가 $72.4 \%$, 여 자가 $27.6 \%$ 로 남녀 성비는 약 2.6:1, 일관적 음운장애 집단은 남자 가 $33.3 \%$, 여자가 $66.7 \%$ 로 남녀 성비가 약 1:2로 나타났다. 말소리 장애 하위유형에 따라 성비에 유의한 차이가 있는지 알아보기 위 해 카이제곱 검정을 실시한 결과, 말소리장애 하위유형 간 성비 차 는 나타나지 않았다.

두 번째, 말소리장애 아동의 출생 전-중-후 문제 여부를 조사하 였다. 임신 및 출산 과정 중 문제는 임신성 고혈압, 전자간증과 같은 임신 중 질병이나 조산, 미숙아, 저체중아, 난산과 같은 출산 과정 중 문제이며, 출생 직후 문제는 고열, 경기, 황달, 신생아 뇌출혈 같 은 출산 직후에 나타날 수 있는 문제로 보았다. 말소리장애 아동 중 임신 및 출산 중 문제가 있었다고 보고된 아동은 $4.8 \%$ 였다. 말소리 장애 하위유형별로 나누어 살펴보면, 임신 및 출산 중 문제가 있었 다고 보고된 경우는 조음장애 $0.0 \%$, 음운지연 $6.9 \%$, 일관적 음운 장애 $11.1 \%$, 비일관적 음운장애 $0.0 \%$ 로 조사되었다. 전체 말소리장 애 아동 중 출생 직후에 문제가 있었다고 보고된 경우는 $0.0 \%$ 였다.

세 번째, 부적절한 빨기 습관은 일상 생활에서 공갈 젖꼭지 사용 과 손가락 빨기가 생후 24 개월 이후까지 나타나는지 조사한 항목 이다(Dodd \& Howard, 2002). 전체 말소리장애 아동 중 부적절한 빨기 습관이 나타난 아동은 $19.4 \%$ 로 나타났다. 말소리장애 하위유 형별로 나누어 살펴보면, 부적절한 빨기 습관이 있는 아동은 조음 장애가 $0.0 \%$, 음운지연 $24.1 \%$, 일관적 음운장애 $22.2 \%$, 비일관적 음운장애가 $25.0 \%$ 였다.

말소리장애 하위유형에 따라 성별 및 생애 초기 문제에 차이가 있는지 알아보기 위해 카이제곱 검정을 실시한 결과, 성비 $\left(\chi^{2}(3)=\right.$ $5.744, p=.125)$, 임신 및 출산 과정 중 문제 $\left(\chi^{2}(3)=2.256, p=.521\right)$, 부 적절한 빨기 습관 $\left(\chi^{2}(3)=3.597, p=.308\right)$ 에서 유의한 차이가 나타나 지 않았다.

\section{삼출성 중이염}

말소리장애 아동의 급격한 청력 변동에 대한 위험요인은 평가 당 
시 삼출성 중이염 여부, 생후 3 년간 연간 2 회 이상 반복적으로 삼출 성 중이염을 않았는지, 삼출성 중이염을 3 주 이상 만성적으로 않았 는지, 혹은 고막 환기관 삽입술 이력이 있는지를 조사하였다. 전체 말소리장애 아동에게서 평가 당시 삼출성 중이염이 있었다고 보고 된 아동과 고막 환기관 삽입술 이력이 있다고 보고된 아동은 없었 다. 따라서 반복적인 삼출성 중이염과 만성 삼출성 중이염 항목만 을 살펴보았다. 말소리장애 아동의 하위유형별 반복적 삼출성 중 이염과 만성 삼출성 중이염 유무는 Table 6에 제시하였다.

말소리장애 아동 중 생후 3 년 이내에 연간 2 회 이상 반복적으로 삼출성 중이염을 않았다고 보고된 아동은 $17.7 \%$ 였다. 말소리장애 하위유형별로 나누어 살펴보면, 반복적으로 삼출성 중이염을 않았 던 경험이 있는 아동은 조음장애 $16.7 \%$, 음운지연 $24.1 \%$, 일관적 음운장애 $11.1 \%$, 비일관적 음운장애 $8.3 \%$ 로 조사되었다.

말소리장애 아동 중 만성적인 삼출성 중이염을 않았던 아동은 $4.8 \%$ 로 나타났다. 말소리장애 하위유형별로 나누어 살펴보면, 만 성적인 삼출성 중이염을 않았던 아동은 조음장애가 $0.0 \%$, 음운지 연 $6.9 \%$, 일관적 음운장애 $11.1 \%$, 비일관적 음운장애가 $0.0 \%$ 였다.

말소리장애 하위유형에 따라 삼출성 중이염 이력에 차이가 있는 지 알아보기 위해 카이제곱 검정을 실시한 결과, 반복적인 삼출성 중이염 이력 $\left(\chi_{(3)}^{2}=1.821, p=.610\right)$, 만성 중이염 이력 $\left(\chi_{(3)}^{2}=2.256\right.$, $p=.521)$ 에서 유의한 차이가 나타나지 않았다.

\section{사회경제적 수준}

말소리장애 아동의 사회경제적 수준은 가정 내 소득, 주 양육자 의 학력, 자녀의 월 교육비에 대해 조사하여 이를 바탕으로 주 성분 분석을 실시하였을 때 가정 내 소득과 주 양육자의 학력이 사회경 제적 수준 요인에 포함되었다. 사회경제적 수준 중 가정 내 소득은 전체 62명 대상자 모두에 대해 조사되었으나 주 양육자의 학력은 조음장애 아동 2 명, 음운지연 아동 4 명의 보호자가 응답하지 않아 말소리장애 아동 56명을 대상으로 살펴보았다.

가정 내 소득을 살펴보면, 전체 말소리장애 아동 중 일반 가정은 $75.8 \%$, 저소득 가정은 $24.2 \%$ 로 나타났다. 말소리장애 하위유형별

Table 6. Otitis media with effusion (OME) history for children with SSDs

\begin{tabular}{lcc}
\hline & Recurrent OME $(\%)$ & Chronic OME $(\%)$ \\
\hline $\mathrm{AD}(\mathrm{N}=12)$ & $2(16.7)$ & $0(0.0)$ \\
$\mathrm{PD}(\mathrm{N}=29)$ & $7(24.1)$ & $2(6.9)$ \\
$\mathrm{CPD}(\mathrm{N}=9)$ & $1(11.1)$ & $1(11.1)$ \\
$\mathrm{IPD}(\mathrm{N}=12)$ & $1(8.3)$ & $0(0.0)$ \\
Total $(\mathrm{N}=62)$ & $11(17.7)$ & $3(4.8)$ \\
\hline
\end{tabular}

$\mathrm{AD}=$ articulation disorder; $\mathrm{PD}=$ phonological delay; $\mathrm{CPD}=$ consistent phonological disorder; IPD = inconsistent phonological disorder.
로 나누어 살펴보면, 조음장애 집단은 일반 가정이 $50.0 \%$, 저소득 가정이 $50.0 \%$ 였으며, 음운지연 집단은 일반 가정이 $75.9 \%$, 저소득 가정이 $24.1 \%$, 일관적 음운장애 집단은 일반 가정이 $88.9 \%$, 저소득 가정이 $11.1 \%$ 였다. 비일관적 음운장애 집단은 일반 가정이 $91.7 \%$, 저소득 가정이 $8.3 \%$ 였다.

말소리장애 아동의 하위유형별 주 양육자의 학력은 Table 7과 같다. 말소리장애 아동 중 주 양육자의 학력이 대학원 이상인 경우 는 $26.8 \%$, 대학교 졸업은 $46.4 \%$, 전문대 졸업은 $12.5 \%$, 대학교 중퇴 는 $1.8 \%$, 고등학교 졸업 이하는 $12.5 \%$ 였다. 말소리장애 하위유형별 로 살펴보면 조음장애 집단은 주 양육자의 학력이 대학원 이상인 경우는 $30.0 \%$, 대학교 졸업은 $40.0 \%$, 전문대 졸업은 $20.0 \%$, 대학교 중퇴는 $0.0 \%$, 고등학교 졸업 이하는 $10.0 \%$ 였다. 음운지연 집단은 주양육자의 학력이 대학원 이상인 경우가 $24.0 \%$, 대학교 졸업은 $52.0 \%$, 전문대 졸업은 $12.0 \%$, 대학교 중퇴는 $0.0 \%$, 고등학교 졸업 이하는 $12.0 \%$ 였다. 일관적 음운장애 집단은 주 양육자의 학력이 대학원 이상인 경우가 $22.2 \%$, 대학교 졸업은 $55.6 \%$, 전문대 졸업과 대학교 중퇴가 $0.0 \%$, 고등학교 졸업 이하는 $22.2 \%$ 로 조사되었다. 비일관적 음운장애 집단의 주 양육자 학력은 대학원 이상과 대학 원 졸업이 각 $33.3 \%$, 전문대 졸업이 $16.7 \%$, 대학교 중퇴나 고등학교 졸업 이하가 $8.3 \%$ 로 보고되었다.

말소리장애 하위유형에 따라 사회경제적 수준에 유의한 차이가 있는지 알아보기 위해 카이제곱 검정을 실시한 결과, 말소리장애 하위유형 간 소득 수준 $\left(\chi^{2}(3)=6.843, p=.077\right)$ 과 주 양육자의 학력 차이는 나타나지 않았다 $\left(\chi^{2}{ }_{(12)}=7.549, p=.819\right)$ 에서 차이는 나타나 지 않았다.

\section{가족력}

말소리장애 아동의 가족력 동반 비율을 살펴보았다. 가족력은 아동의 직계, 방계 가족에게서 말, 언어, 의사소통 발달이 지연된 구성원이 있는지 조사하였다. 전체 말소리장애 아동 중 가족력이

Table 7. Educational background of the primary caregiver for children with SSDs

\begin{tabular}{lccccc}
\hline & $\begin{array}{c}\text { Higher than } \\
\text { master's } \\
\text { degree }(\%)\end{array}$ & $\begin{array}{c}\text { Bachelor's } \\
\text { degree } \\
(\%)\end{array}$ & $\begin{array}{c}\text { Associate's } \\
\text { degree } \\
(\%)\end{array}$ & $\begin{array}{c}\text { College } \\
\text { dropout } \\
(\%)\end{array}$ & $\begin{array}{c}\text { Lower than } \\
\text { high school } \\
\text { graduate } \\
(\%)\end{array}$ \\
\hline $\mathrm{AD}(\mathrm{N}=10)$ & $3(30.0)$ & $4(40.0)$ & $2(20.0)$ & $0(0.0)$ & $1(10.0)$ \\
$\mathrm{PD}(\mathrm{N}=25)$ & $6(24.0)$ & $13(52.0)$ & $3(12.0)$ & $0(0.0)$ & $3(12.0)$ \\
$\mathrm{CPD}(\mathrm{N}=9)$ & $2(22.2)$ & $5(55.6)$ & $0(0.0)$ & $0(0.0)$ & $2(22.2)$ \\
$\mathrm{IPD}(\mathrm{N}=12)$ & $4(33.3)$ & $4(33.3)$ & $2(16.7)$ & $1(8.3)$ & $1(8.3)$ \\
Total $(\mathrm{N}=56)$ & $15(26.8)$ & $26(46.4)$ & $7(12.5)$ & $1(1.8)$ & $7(12.5)$ \\
\hline
\end{tabular}

$\mathrm{AD}=$ articulation disorder; $\mathrm{PD}=$ phonological delay; $\mathrm{CPD}=$ consistent phonological disorder; IPD= inconsistent phonological disorder. 
있는 아동은 $37.1 \%$ 였다. 말소리장애 하위유형별로 나누어 살펴보 면, 가족력이 있다고 보고된 경우는 조음장애 $25.0 \%$, 음운지연 $37.9 \%$, 일관적 음운장애 $44.4 \%$, 비일관적 음운장애 $41.7 \%$ 로 조사 되었다. 말소리장애 하위유형에 따라 가족력 유무에 유의한 차이 가 있는지 알아보기 위해카이제곱 검정을 실시한 결과, 말소리장애 하위유형 간 가족력 유무의 차이는 나타나지 않았다 $\left(\chi^{2}(3)=1.077\right.$, $p=.783)$.

\section{논의 및 결론}

본 연구는 3-9세 말소리장애 아동을 대상으로 말소리장애의 지 속성과 중증도에 영향을 미칠 가능성이 있는 여러 위험요인을 얼 마나 동반하고 있는지 조사하고, 말소리장애 하위유형별로 주요 위험요인 분포에 유의한 차이가 있는지 살펴보고자 하였다.

말소리장애 문헌에서 보고된 총 22개의 위험요인 측정치(성별, 인지, 임신 및 출산 중 문제, 출생 직후 문제, 평가 당시 삼출성 중이 염, 반복적인 중이염, 만성 중이염, 고막 환기관 삽입술, 설소대 수 술, 부적절한 빨기 습관, 가정 내 소득 수준, 주 양육자의 학력, 자녀 의 월 교육비, 전체적인 사회경제적 수준, 이중언어환경, 가족력, 첫 낱말 시작 시기, 언어지연, 스스로 걷기 시기, 전반적 발달 지연, 언 어 치료력, 타 영역 치료력) 중 14 개 위험요인에 대해 주성분분석 실 시가 가능하였다. 말소리장애와 관련된 위험요인의 주성분분석 결 과, 14 개 위험요인은 1) 언어 및 신체 발달, 2) 성별 및 생애 초기 문 제, 3) 삼출성 중이염, 4) 사회경제적 수준, 5) 가족력으로 크게 5개 측면으로 구분되었다. 이는 위험요인을 4 개 측면으로 요약한 선행 연구 결과와 유사하였다(Eadie et al., 2015; Fox et al., 2002). Eadie 등(2015)은 말소리장애 위험요인을 (1) 아동 및 가족 요인: 조산, 형 제 수, 출생 순서, 출생 시 몸무게, (2) 생애 초기 부모 보고에 의한 말 요인: 생애 초기 말 발달, 음절성 발성의 수와 유형, (3) 인지-언어 요인: 2 세 경 표현 어휘, (4) 생애 초기 부모 보고에 의한 운동 능력: 팔/다리 움직임, 손/손가락 움직임, 블럭 쌓기 가능 여부로 정리하 였다. 마찬가지로 Fox 등(2002)은 말소리장애 아동에게 7개 위험요 인(임신 중 문제, 출생 직후 문제, 급성 중이염, 급성 청력 변동요인, 청력 문제, 젖병/엄지손가락/공갈 젖꼭지 빨기 습관, 가족력)을 조 사한 후 (1) 가족력, (2) 출생 중 문제, (3) 청력 변동 요인, (4) 부적절 한 빨기 습관을 네 가지 요인으로 정리하였다. 본 연구는 문헌 조사 를 통해 위험요인을 탐색하고 주성분분석 방법을 통해 체계적으로 주요 위험요인을 도출하고 제시한데 의의가 있다.

본 연구에서 도출된 첫번째 요인인 '언어 및 신체 발달'은 첫 낱말 출현 시기, 언어지연, 스스로 걷기 시기, 전반적 발달 지연, 언어 치
료력, 타 영역 치료력이 포함되었다. 이 중 ' 24 개월경 전반적 발달 지 연'은 카이제곱 분석 결과 유일하게 말소리장애 하위유형별로 유의 한 차이를 보였다. 2 세 경 전반적 발달 지연은 말소리장애 아동의 $27.4 \%$ 가 경험했다고 보고되었으며 이 중에서도 음운지연 아동은 절반 가까이 전반적 발달 지연을 겪었다고 보고하였다. 이러한 결 과는 Fox 등(2002)에서도 동일하였다. Fox 등(2002)은 성별, SES, 초기 언어 발달, 가족력, 생애 초기 건강상태, 청력 변동, 섭식, 전반 적 발달, 행동 문제, 이중언어, 형제 수, 육아 중 염려사항처럼 말소 리장애 아동의 12 개 위험요인 대해 조사하였는데 이 중 전반적 발 달 측면에서만 유의한 차이가 나타났으며 음운지연 아동군의 $30 \%$ 이상이 전반적 발달 지연을 겪었다고 보고되었다. 선행연구와 본 연 구 결과를 종합해보면 영유아기에 신체, 정서 및 인지를 포함한 전 반적인 발달 측면은 이후 3 세 이후의 말소리장애와 밀접한 관련이 있을 가능성을 시사하며 말소리 문제를 유지 또는 악화시킬 수 있 는 위험요인으로써 생애 초기에 아동의 전반적인 발달을 면밀하게 살펴볼 필요가 있다.

말소리장애 아동의 언어 발달과 관련된 첫 낱말과 2 세 경 언어지 연과 관련된 면담 내용을 살펴보면 말소리장애 아동 중 첫 낱말이 18 개월 이후에 나타난 경우는 $17.7 \%$ 로 비교적 적었으나 2 세 경 언 어 발달 지연 항목은 $64.5 \%$ 에게서 보고되었다. 또한 언어 발달 지 연은 말소리장애 4 개 하위유형의 종류와 무관하게 모든 집단에서 과반수 이상 보고되었다. 따라서 말소리장애 아동의 언어장애 동 반 가능성을 염두에 두고 평가 및 중재가 이루어져야 할 것이다.

말소리장애 아동의 치료 경험에 대해 조사하였을 때 언어재활서 비스를 받는 중이거나 받았던 경험이 있는 아동은 $38.7 \%$, 언어재활 서비스 외에 심리, 놀이, 인지, 미술, 감각통합 등 재활서비스를 받는 중이거나 받았던 아동은 $17.7 \%$ 로 조사되었다. 말소리장애 아동이 기저 결함이나 동반장애가 없더라도 특정 영역에서 서비스가 요구 될 수 있으므로 임상 현장에서 아동의 수행력에 대해 관찰한 뒤 개 인차를 고려하여 중재를 진행해야 할 것이다.

두번째 요인인 '성별 및 생애 초기 문제'는 성별, 임신 및 출산 과 정 중 문제, 부적절한 빨기 습관이 포함되었다. 성별은 말소리장애 에 영향을 미칠 수 있는 요인으로 본 연구에서도 남아와 여아의 비 율이 2:1로 나타나 타 연구 결과들과 유사하였다(Broomfield \& Dodd, 2004; Eadie et al., 2015; Fox et al., 2001). 통계적으로 유의한 차이가 나타나지는 않았으나 비일관적 음운장애와 조음장애군에 서 남아의 비율은 여아 대비 3:1이었으므로 성별이 소리장애 중증 도나 지속 기간에 영향을 미칠 수 있음을 염두에 두어야 할 것이다.

임신 및 출산 과정 중 문제는 말소리장애 아동의 $4.8 \%$ 에게서만 보고되어 말소리장애 아동과 밀접한 영향이 없는 것으로 사료된 
다. 또한 출생 직후 문제는 모든 말소리장애 아동에게서 나타나지 않았다고 보고된 항목이었다. 출생 직후 문제는 신생아 중환자실 에 1 주일 이상 입원을 요하는 질병을 기준으로 조사하였다. 이러한 질병은 아동에게 구조적인 문제가 동반되었다는 신호이거나, 질병 으로 인해 신경학적 문제를 야기할 수 있으므로 원인을 모르는 말 소리장애 아동은 임신이나 출산 중, 출생 직후 문제를 동반하지 않 은 것으로 보인다.

부적절한 빨기 습관은 말소리장애 아동의 $19.4 \%$ 에게서 나타났 었다고 보고되었다. 조음장애 아동만 빼고 모든 하위유형에서 $20 \%$ 이상 아동이 24 개월 이후에도 엄지손가락이나 공갈 젖꼭지 등을 과도하게 빠는 모습이 관찰되었다고 하였다. 즉, 부적절한 빨기 습 관이 구강인식 능력과 구강 운동 능력을 포함하여 말 발달에 부정 적인 영향을 끼쳤을 가능성을 시사한다(Fox et al., 2002). 그러므로 영유아기에 정해진 시간 이외에 부적절한 빨기 습관을 가진 아동은 해당 습관을 소거할 수 있도록 도움을 주어야 할 것이다.

세번째 요인인 '삼출성 중이염'은 반복적 삼출성 중이염과 만성 삼출성 중이염 이력이 포함되었다. '말소리장애 아동의 반복적 삼 출성 중이염 병력은 $17.7 \%$ 에게서 보고되었으며 만성 삼출성 중이 염에 대한 병력은 $4.8 \%$ 로 보고되었다. 반복적인 삼출성 중이염은 전도성 난청을 야기하여 아동의 말 지각과 말 발달에 부정적인 영 향을 미칠 수 있으므로 말소리장애 아동에게 반복적인 삼출성 중 이염이 있었는지 임상현장에서 확인하고 평가를 진행하며, 더불어 현재 청력 수준을 확인할 수 있다면 더욱 바람직할 것이다.

본 연구에서는 현재 삼출성 중이염 유무에 대해서 구두로 조사 하였으며 현재 삼출성 중이염이 있다고 보고된 아동은 아무도 없 었다. 그러나 삼출성 중이염은 통증 없이 저류액만 차 있는 경우가 있으며 이 경우에는 주 양육자가 알지 못하는 경우도 있을 수 있다 (Bernthal et al., 2017; Chung \& Jo, 1999). 따라서 추후 연구에서는 이경으로 삼출성 중이염 여부를 직접 관찰한다면 정확한 조사에 도움이 될 것이다.

네번째 요인인 '사회경제적 수준’은 가정 내 소득과 주 양육자의 학력 측정치가 포함되었다. 말소리장애 아동의 사회경제적 수준에 대해 조사하였을 때 자녀의 월 교육비와 사회경제적 수준 종합지표 는 요인적재량이 적어 주성분분석을 실시할 수 없었다. 즉, 사회경 제적 수준을 조사할 때 가정 내 소득과 주 양육자의 학력이 아동 가정의 사회경제적 수준을 보다 적절하게 반영하는 측정치라는 점 을 알 수 있다. 통계적으로 유의한 차이가 나타나지는 않았으나 말 소리장애 아동 중 $25 \%$ 가 저소득 가정이었다는 점은 염두에 두어야 할 것이다.

마지막 위험요인으로 '가족력’이 도출되었다. 본 연구에서 말소리
장애 하위유형별로 가족 구성원이 말, 언어, 의사소통에 어려움을 동반하는 사람이 있는지 조사한 가족력 동반 비율은 25-44\%로 조 사되었다. 특히 일관적, 비일관적 음운장애 아동의 가족력은 $40 \%$ 이상이었다. 통계적으로 유의하지는 않았으나 음운장애 집단에게 서 가족력이 비교적 높게 나타난 결과는, 선행연구에서 가족력이 있는 말소리장애 아동은 특정한 집단을 따로 이루는 듯한 양상을 보인다는 해석과 맥을 같이 한다(Lewis \& Freebarin, 1997). 따라서 말소리장애 아동의 평가 시 가족력을 조사하고 확인해 볼 필요가 있다.

우리나라 말소리장애 아동을 대상으로 위험요인 동반 여부를 광 범위하게 제시한 선행 연구가 없었다. 본 연구는 말소리장애 위험요 인으로 선행 연구에서 언급되었던 22개 위험요인 모두를 자세하게 조사하였다. 그 결과, 만 2 세 경 발달 지연 여부가 말소리장애 아동 하위유형 간 다른 것으로 조사되었다. 이는 말소리장애 아동 중에 서도 생애 초기에 전반적으로 더딘 발달을 보였다고 보고되는 아 동을 면밀하게 살펴보고 조기 평가 및 조기 중재를 계획해야 한다 는 점을 시사하였다. 따라서 본 연구 결과는 우리나라 말소리장애 아동의 위험요인 특성을 면밀하게 이해하는데 중요한 자료가 되었 다는 점에서 연구에 의의가 있다.

하지만 본 연구는 대조군인 일반 아동이 없으므로 위험요인 관 련 측정치에서 일반 아동과의 비교를 실시할 수 없었다. 해당 연구 결과가 말소리장애 아동 고유의 특성인지, 일반 아동을 포함한 전 반적인 인구 특성인지 비교하기 위해 일반 아동과의 분포 비율 비 교는 반드시 필요할 것이다. 또한 본 연구는 주 양육자의 보고에 의 한 후향적 연구로 면담의 신뢰성을 전부 입증하기 어렵다. 따라서 이후에는 말소리장애 위험군 아동을 대상으로 영유아기부터 종단 연구를 진행하여 말소리장애 아동의 하위유형별 위험요인 현황을 보다 실질적이고 체계적으로 알아본 뒤 위험요인이 말소리장애 하 위유형을 예측할 수 있는지 조사해 보아야 할 것이다. 또한 62 명의 말소리장애 아동을 대상으로 위험요인 현황을 직접 조사하여 살펴 본 점은 의의가 있으나 언어학적 증상에 따른 말소리장애 하위유형 별 분포가 고르지 않고 일관적 음운장애 아동 수가 적어 하위유형 별 위험요인 현황을 체계적으로 살펴보는 것이 제한적이었다. 따라 서 추후 지속적인 연구를 통해 어떤 위험요인이 특정 말소리장애 하위유형과 더 관련이 있는지 살펴볼 필요가 있다.

\section{REFERENCES}

Ahn, S. W., Lee, C. H., Kim, Y., Shin, Y. J., \& Park, W. K. (2007). A Study of the effect of parent's social economic status on phonological awareness 
ability in children. The Journal of Special Education: Theory and Practice, 8(3), 533-550.

Balladares, J., Marshall, C., \& Griffiths, Y. (2016). Socio-economic status affects sentence repetition, but not non-word repetition, in Chilean preschoolers. First Language, 36(3), 338-351.

Bernthal, J., Bankson, N. W., \& Flipsen, Jr. P. (2017). Articulation and phonological disorders: speech sound disorders in children. New York, NY: Pearson.

Broomfield, J., \& Dodd, B. (2004). The nature of referred subtypes of primary speech disability. Child Language Teaching and Therapy, 20(2), 135-151.

Brown, B. B., \& Edwards, M. (1989). Developmental disorders of language. London: Whurr.

Chung, M., \& Jo, S. (1999). Diagnosis and treatment of otitis media in children. Journal of Clinical Otolaryngol, 10(2), 123-134.

Dodd, B. (2005). Differential diagnosis and treatment of children with of speech disorder (2nd ed.). London: Whurr

Dodd, B. (2014). Differential diagnosis of pediatric speech sound disorder. Current Developmental Disorders Reports, 1(3), 189-196.

Eadie, P., Morgan, A., Ukoumunne, O. C., Ttofari Eecen, K., Wake, M., \& Reilly, S. (2015). Speech sound disorder at 4 years: prevalence, comorbidities, and predictors in a community cohort of children. Developmental Medicine \& Child Neurology, 57(6), 578-584.

Fox, A. V., Dodd, B., \& Howard, D. (2002). Risk factors for speech disorders in children. International Journal of Language \& Communication Disorders, 37(2), 117-131.

Garliner, D. (1971). Let us talk about thumb sucking. Brooklyn: Bartel Dental.

Ha, S., Kim, M., Seo, D. G., \& Pi, M. (2021). Korean articulation phonology profile. Seoul: Human Brain Research and Consulting.

Kaiser, H. F. (1974). An index of factorial simplicity. Psychometrika, 39(1), 31-36.

Kim, M. J., Pae, S., \& Park, C. I. (2007). Assessment of phonology and articulation for children (APAC). Seoul: Human Brain.

Kim, S. J., \& Kim, S. Y. (2009). The effect of home environment on children's linguistic ability. Korean Journal of Child Studies, 30(5), 87-102.

Lewis, B. A., \& Freebairn, L. (1997). Subgrouping children with familial phonologic disorders. Journal of Communication Disorders, 30(5), 385-402.

Lewis, B. A., Shriberg, L. D., Freebairn, L. A., Hansen, A. J., Stein, C. M., Tay- lor, H. G., \& Iyengar, S. K. (2006). The genetic bases of speech sound disorders: evidence from spoken and written language. Journal of Speech, Language, and Hearing Research, 49(6), 1294-312.

Park, H. (2014). Korean version of comprehensive test of nonverbal intelligence second edition (K-CTONI-2). Seoul: Mindpress.

Park, H., Lee, K., \& Ahn, D. (2015). Korean-Wechsler preschool and primary scale of intelligence-fourth edition (K-WPPSI-IV). Seoul: Hakjisa.

Pascoe, M., Stackhouse, J., \& Wells, B. (2005). Phonological therapy within a psycholinguistic framework: promoting change in a child with persisting speech difficulties. International Journal of Language \& Communication Disorders, 40(2), 189-220.

Paul, R. (1991). Profiles of toddlers with slow expressive language development. Topics in Language Disorders, 11(4), 1-13.

Paul, R., \& Jennings, P. (1992). Phonological behavior in toddlers with slow expressive language development. Journal of Speech, Language, and Hearing Research, 35(1), 99-107.

Pi, M., \& Ha, S. (2020). Classification of subgroups of children with speech sound disorders: a preliminary study. Communication Sciences \& Disorders, 25(1), 114-126.

Rescorla, L. (1989). The language development survey a screening tool for delayed language in toddlers. Journal of Speech and Hearing Disorders, 54(4), 587-599.

Shim, H. S., Song, Y. K., \& Jin, S. M. (2005). Speech perception and phonological characteristics of children with episodes of recurrent otitis media with effusion. Korean Journal of Communication \& Disorders, 10, 80-100.

Shriberg, L. D., Fourakis, M., Hall, S. D., Karlsson, H. B., Lohmeier, H. L., McSweeny, J. L., ..., \& Tilkens, C. M. (2010). Extensions to the speech disorders classification system (SDCS). Clinical Linguistics \& Phonetics, 24(10), 795824.

So, G., \& Ha, S. (2020). Vocabulary, articulation, phonological awareness and cognition by children's grade and parents' income-level. Journal of SpeechLanguage \& Hearing Disorders, 29(2), 157-164.

Stackhouse, J., \& Wells, B. (1997). Children's speech and literacy difficulties I: a psycholinguistic framework. London: Whurr.

Thal, D., \& Bates, E. (1988). Language and gesture in late talkers. Journal of Speech, Language, and Hearing Research, 31(1), 115-123. 


\section{국문초록}

\section{언어학적 증상에 따른 말소리장애 아동의 하위유형별 위험요인}

피민경 $\cdot$ 하승희 ${ }^{2}$

'한림대학교 대학원 언어병리청각학과, ${ }^{2}$ 한림대학교 언어청각학부, 청각언어연구소

배경 및 목적: 본 연구는 말소리장애 아동에게 22개 위험요인에 대해 조사하고 위험요인이 말소리장애 하위유형에 따라 차이가 있는 지 알아보고자 하였다. 또한, 말소리장애 위험요인이 Dodd의 감별진단모델 하위유형을 판별할 수 있는지 조사하고자 하였다. 방법: 본 연구는 3-9세 말소리장애 아동 62명이 참여하였으며 부모 면담과 비구어 인지 평가를 통해 22개 위험요인에 대해 조사하였다. 말소리장 애 아동은 조음장애, 음운지연, 일관적/비일관적 음운장애 집단으로 분류하였다. 결과: 주 성분분석 결과, 22개 위험요인은 1) 언어 및 신체 발달, 2) 성별 및 생애 초기 문제, 3) 삼출성 중이염, 4) 사회경제적 수준,5) 가족력으로 축약되었다. 2세 경 전반적 발달 지연 항목에 서만 말소리장애 하위유형별 차이가 나타났다. 논의 및 결론: 본 연구는 말소리장애 아동의 위험요인을 직접 조사하고 다수의 위험요 인을 다섯 가지로 축약하여 살펴본 것에 의의가 있다. 또한 말소리장애 아동 중에서도 2 세 경에 신체, 정서 및 인지를 포함한 전반적인 발달이 지연되었다고 보고된 아동을 면밀하게 살펴보고 조기 평가 및 중재를 계획해야한다는 점을 시사하였다.

핵심어: 말소리장애, Dodd의 감별진단모델, 위험요인, 주성분분석

\section{참고문헌}

김민정, 배소영, 박창일 (2007). 아동용 발음평가(APAC). 서울: 휴브알앤씨.

김수진, 김수영 (2009). 가정환경변인이 유아의 언어능력에 미치는 영향. 아동학회지, 30(5), 87-102.

박혜원 (2014). 한국 비언어지능검사 2판(K-CTONI-2). 서울: 마인드프레스.

박혜원, 이경옥, 안동현 (2015). 한국 웩슬러 유아지능검사 4판(K-WPPSI-IV). 서울: 학지사.

소금빈, 하승희 (2020). 아동의 학년과 부모의 소득 수준에 따른 어휘, 조음, 음운인식 및 인지 능력의 차이. 언어치료연구, 29(2), 157-164.

심현섭, 송윤경, 진성민 (2005). 삼출성 중이염 반복감염 아동의 말소리 지각 및 조음·음운 특성. 언어청각장애연구, 10, 80-100.

안성우, 이창환, 김유, 신영주, 박원경 (2007). 부모의 사회, 경제적 지위에 따른 아동들의 음운 인식수행 능력 비교 연구. 특수교육 저널: 이론과 실천,

8(3), 533-550.

정명현, 조성우 (1999). 소아중이염의 진단과 치료. 임상이비인후과, 10(2), 123-134.

피민경, 하승희 (2020). 말소리장애 아동의 하위유형 분류를 위한 예비 연구. Communication Sciences \& Disorders, 25(1), 113-125.

하승희, 김민정, 서동기, 피민경 (2021). 한국 조음음운 프로파일(K-APP). 서울: 휴브알앤씨.

\section{ORCID}

피민경(제 1저자, 대학원생 https://orcid.org/0000-0002-9093-8005); 하승희(교신저자, 교수 https://orcid.org/0000-0003-2133-3720) 